\title{
Teaching of Remedial English and the Problems of the Students: A Case of University of Sindh, Jamshoro, Sindh, Pakistan
}

\author{
Zafarullah Sahito ${ }^{1, *}$, Abida Siddiqui ${ }^{2}$, Mumtaz Khawaja ${ }^{3}$, Anjum Shaheen ${ }^{3}$, Humera Saeed ${ }^{4}$ \& Sajad Haider Laghari ${ }^{4}$ \\ ${ }^{1}$ School of Applied Educational Science and Teacher Education, Philosophical Faculty, University of Eastern \\ Finland, Joensuu \& Department of Education, Sukkur IBA, Sindh, Pakistan \\ ${ }^{2}$ Department of Educational Management and Supervision, Faculty of Education, University of Sindh, Elsa Kazi \\ campus, Hyderabad, Sindh, Pakistan \\ ${ }^{3}$ Department of Education, Faculty of Education, University of Sindh, Elsa Kazi Campus, Hyderabad, Sindh, \\ Pakistan \\ ${ }^{4}$ Literacy and Education Department, Government of Sindh, Pakistan \\ *Correspondence: School of Applied Educational Science and Teacher Education, Philosophical Faculty, University \\ of Eastern Finland, Joensuu \& Department of Education, Sukkur IBA, Sindh, Pakistan. E-mail: \\ zafarullah.sahito@gmail.com
}

Received: January 4, 2017

Accepted: January 19, 2017 Online Published: February 26, 2017

doi:10.5430/wjel.v7n1p1

URL: http://dx.doi.org/10.5430/wjel.v7n1p1

\begin{abstract}
The research paper is designed to explore the achievement of the aims and objectives of teaching remedial English. It also aims to know the importance of the course and the problems of the students regarding the teaching of remedial English at university level in Pakistan with special reference to university of Sindh, Jamshoro. In this regard many efforts were taken by the tutors, lecturers, assistant professors, professors and the administration of the university to enhance the capabilities and efficiencies of the students of undergraduate level. All students of undergraduate level and the teachers who take remedial English classes are constituted as the Population of the study. Five $(n=5)$ teachers who teach remedial classes and forty $(n=40)$ students from different departments were recruited as the sample of the study through purposive and random sampling techniques. Interviews were conducted from students and tutors who attend and teach remedial English course respectively. 90\% students found unsatisfied from the administration of the classes and they stressed that the classes should be conducted separately at department level and they demanded for the basic needed facilities during the classes such as the facility of language laboratory, availability of computers, multimedia, audio and video resources in order to accelerate and enhance the teaching learning process to improve English language skills.
\end{abstract}

Keywords: teaching; remedial English; problems of students

\section{Introduction}

Language is a way of communication of thoughts and feelings through a system of arbitrary signals, such as voice sounds, gestures, postures and written symbols. It includes its rules for combining its components, such as words, sentences, etc. Language may be the most suitable distinguishing characteristicness by which to arrange systematically in classes of humans with in the system of nature, even more on the basis of rationality (Homo sapiens) or technology. It is not because of the language is more expressive than rationality and more natural than technology. In a sense Homo Loquens generously cover all other terms, since the very deed of (exact meaning) definition is itself runs with in language. The language which is first learned is called the native of the children or the mother tongue. Both of these language terms mother and second / non-mother tongue are Metaphorical in which the knowledge of any particular language is gained through behaviour not inherited. Almost from $20^{\text {th }}$ century on wards linguistics have displayed keen interest in knowing about the theory that no one is born with a predisposition towards any language, but contrary all human beings are genetically/biologically endowed with the ability to learn and use language in general and proper way. Noam Chomsky the inventor of the theory of Transformal/Generative grammar 
in 1950s. In this theory he is of opinion that the idiosyncratic vocabulary and grammatical convention of any natural language rest on a foundation of deep structures. The theory of universal grammar underlying all languages and their correspondence to an innate capacity of the human brain. This theory directly hints not only that there are restricts on what should make/constitute an intelligible or easily understood human language, but along with it however number of things are striking, like the differences between the two languages are less fundamental or important than their similarities. Some of the individuals have been successfully in constructing their own artificial various purposes like for practical, experimental, personal and ideological reasons.

\subsection{English as an International Language}

English language belongs to the Germanic languages branch of the Indo-European language family, widely spoken in six continents. It's a primary language of the U.S., Britain, Canada, Australia, Ireland, New Zealand, and various Caribbean and Pacific island nations. It is also an official language of India, the Philippines, and many sub-Saharan African countries. It is the second most widely spoken native language in the world, the mother tongue of more than 350 million people, and the most widely taught foreign language, and the international language of science, business, economics, development and technology. English has got great success in replacing French language as the international vehicle of expression for many reasons especially for the political, military and economical dominance of the United States of America since the World War-II (1939-1945). Together the influence of American culture, like movies, television. Music (rock music), books, science fictions, etc have really increased at large the importance of English language. We were well on our way to this position before Pearl Harbor drew us into war in 1941. Mencken attributes this partly to the "dispersion of the English-speaking peoples," but in typical Mencken style goes on to say that those peoples "have been, on the whole, poor linguists, and so they have dragged their language with them, and forced it upon the human race." Robert MacNeil, in the fascinating study of the English language for the Public Broadcasting System (PBS), The Story of English (1986), observed that when landing in Rome, an Italian pilot flying an Italian airliner converses with the control tower in English.

Remedial, the word which is the adjective of the noun Remedy means "providing or intended to provide a remedy or cure". So, this intended remedy was planned to provide those who need it at bad time. By the well wishers, administrators of the universities of Pakistan and under the great supervision and recommendation of Higher Education Commission this programme of remedial English was started in different universities of Pakistan. University of Sindh, Jamshoro the second oldest university of Pakistan was also started the same programme of remedial English in 2000 and 2001 sessions. This newly introduced programme replaced the old English compulsory course and for this the new teachers were also appointed from the department of English and outside of the University as visiting faculty.

Firstly, this programme was introduced at B.A and B.Sc levels. But later on the amendments were made in the programme when the BS and MS programmes were introduced by the Higher Education Commission. Now this programme is also running for the students of M.A and M.Sc previous on regular as well as on combined basis.

The objectives behind introducing this programme of remedial English were:

- To teach English at university level in order to improve the skills of students.

- To improve and enhance the knowledge of students through English language.

- To improve the quality and research in different fields of education through English language.

The remedial English was introduced with many new objectives and the new out lines were made in order to modify the previous course but the things were remain almost similar because no proper attention and training were given to the teachers. That's why teachers followed the out lines with the help of old books. So, the teachers and the students were faced to use books whatever they come across in the libraries and markets but on the other side the plan of the remedial English had wanted many more things to suffice its needs. In the existing system of remedial English the required materials, planning, time management, etc were not seemed to utilize properly according the need and the requirement of the nature of the subject, teachers and students. In 2006 some demands were fulfilled when the University of Sindh published specific books after the university of Karachi and Punjab with the coordination and cooperation of Oxford University Press, Pakistan. University of Sindh carried many changes in new books with the cooperation of Oxford University Press in two books i.e. English for Under Graduates by D. H. Howe and Oxford Practice Grammar by John East Wood. These books are divided into four parts, first two parts are described for the students of B.A, B.S part-I, M.A and M.Sc previous and remaining two parts are for the students of B.A, B.S part-II, M.A and M.Sc final. 


\subsection{Statement of the Problem}

Through this study the factors and causes are identified which increase the problems of students to learn well and get good grades in their studies. The effect of the factors could be checked on the smooth running of the teaching-learning process of remedial English at university level. In this connection the physical facilities are diagnosed and availability of human and material resources are also checked in order to find out the problems of students. The suggestions would be given for the improvement of the policies and the practices which were implemented during previous years. It would also be checked and may be suggested that the teaching-learning process can be improved through the cooperation, coordination, the healthy teaching learning environment and the direct and indirect participation of the teachers, heads and availability of required physical facilities in each and every department and institute of the university in order to meet the modern requirements of the world.

\subsection{Objectives of the Study}

- To know about the importance of teaching remedial English subject among students.

- To find out the problems faced by students during remedial English classes.

- To explore the causes of problems of students during teaching remedial English.

- To explore the effect of faced problems of students on their learning language skills.

\subsection{Delimitations of the Study}

This study is delimited up to the students of undergraduate level of different departments and institutes of the Allama I. I. Kazi, new Campus and Elsa kazi, old campus University of Sindh, Jamshoro and the teachers (tutors) who are working and have worked in past years.

\section{Literature Review}

The problem of quality of English language teachers has always remained unsolved in Pakistan (Government of Pakistan, 2009), that's why almost all educational polices and plans have discussion the need of quality English language teachers in Pakistan (Memon, 2007; Shami \& Hussain, 2006). The main hurdles were lack of funds and political will has been remained a strong hurdle in the quality of English language teachers (Iqbal \& Ahmed, 2010). Quality varies from context to context, institute to institute and person to person, for a university it can be interpreted as an instrument by which the objectives are to be achieved (Ismail, 2010) as how good any educational institutions are offering their services to their students (Seyfried, 2007). It consists of two dimensions such as relevance and excellence (Ullah, 2005), where excellence is the degree depending on goodness of service is compared to standard (Irfan \& Kee, 2013). The product of higher education system of Pakistan cannot compete internationally due to unavailability of quality English language teachers (Aadil, 2010; Shah, 2010), who are also facing a number of problems and they have a great impact on the quality (Batool \& Qureshi, 2007). There are many challenges and problems available here in Pakistani education system such as non-flexible admission criteria, lack of qualified faculty, supervisors lack local field experience, lack of collaboration with both local and international researchers and job market, lack of seriousness and lack of brand (Aadil, 2010; Iqbal, 2004).

Pakistanis as they are multilingual people, have to take up the study of a major foreign language for purposes of international communication. The people in this sub-continent started learning English because it was the language of the rulers. The British rulers wanted to run the machinery of the Government with the help of cheap labour available on the native soil. So they offered all possible encouragement to those people who took up the study of English. As their feet hold grew stronger, they planned to colour the very mental makeup of the entire native population through the medium of English. English as a medium of instruction has a very weak case. But there is growing realization among the intelligentsia that the study of English as a means of intercommunication with the rest of the world is a valuable asset which we cannot afford to lose. English has now come to acquire an international status and no nation can afford to ignore it-much less. In this connection the universities of Pakistan also give a great attention and concentration on the improvement of English language of their students at all levels. Most of the universities started the programmes of learning English known as Remedial English consists of improving the reading, writing and speaking skills of students. The selected books for this course are fully supported to improve the oral and written skills of the students.

Reading is considered the primary tool for learning anything in school and classroom environment as it is said that the literate persons can acquire vast and diverse knowledge and experiences through written literature (UNESCO, 1983). Because reading fulfills many purposes such as personal, social, socio-civic, avocational, professional, 
technical, intellectual, spiritual needs, interests, demands and values (Gray \& Rogers, 1956) to serve as a high speed vehicle for self-improvement, extension of cultural and linguistic background in order to find the answers of questions that satisfy the curiosity of the learner (Harvey, 1998). Although reading is considered the complex process (NCTE, 2006) that involves the cognitive processes (Morrow \& Tracey, 2012) and strategies such as word reading or decoding, fluency, vocabulary and comprehension (Denton, Bryan, Wexler, Reed \& Vaughn, 2007). As a student may read text with speed, accuracy and proper expression where attention can be allocated to comprehension (Wolf \& Katzir-Cohen, 2001) and specifically to read a text related their course and grade (Harn, Stoolmiller \& Chard, 2008; Jenkins, Hudson \& Johnson, 2007; Hasbrouck \& Tindal, 2006; Katzir, Kim, Wolf, O’Brien, Kennedy \& Lovett, 2006; Francis, Fletcher, Stuebing, Lyon, Shaywitz \& Shaywitz, 2005). Oral fluency is frequently described in different studies as having three major dimensions such as word reading accuracy; automaticity or word reading rate or pace and prosody (Rasinski, 2006). Word reading accuracy dimension refers to the phonics skills and the decoding words; while automaticity refers to the processing of texts; and Prosody the third and last dimension refers to the oral fluency. It is the capacity that enable the students to make oral reading sound like spoken language (Stahl \& Kuhn, 2002), melodic element in reading (Rasinski, Rikli \& Johnston, 2009) bridging towards comprehension (Rasinski, 2006; Pikulski \& Chard, 2005; Schreiber, 1991) to understand the text (Rasinski, 2004).

The research findings state that there was a positive correlation between the age and the English oral fluency of the learners and no significant differences in their oral fluency level, gender and year of study (Estrada, 2016). For teaching English as a foreign language (TEFL) teacher knowledge is a multidimensional construct and pedagogical content knowledge (PCK) is closely related to both content knowledge (CK) and general pedagogical knowledge (GPK) of preservice teachers in Germany (König, Lammerding, Nold, Rohde, Strauß \& Tachtsoglou, 2016). That's why the cultural models inheritance in the institutional policy was negotiated and demanded by the teachers to avoid the contemporary context of restrictive educational policies and proper and positive implications for all stakeholders in order to get professional and collaborative support for objectives achievement of the course, program and organization (Heineke, 2015). In this regard the aspects and perspectives of classrooms' life and environment which explored and engaged outside the western world at educational institutes (Howe, 2005; Tafa, 2004; O'Sullivan, 2004; Roberts-Holmes, 2003) focus on the English language teaching in classroom particularly (Simon-Maeda, 2004; Al-Belushi, 2003; Tsui, 2003; Canagarajah, 1999b) that positively impacts on the learning of students. These all are directly concern with the careers of English teachers and their career development (Al-Belushi, 2003); English teachers' life experiences and backgrounds influence on their teaching, the social dimension of teaching, choice of classroom materials and topics to teach (Tsui, 2003). In USA, the classrooms are more linguistically diverse than ever before (Gandara \& Hopkins, 2010) because the enrollment of English learners (ELs) is increased from 3.5 million to 5.3 million (NCELA, 2012). Due to increase in population across the USA, schools are unable to meet the needs of ELs, who demonstrate lower academic achievement continuously at their institutions (Gandara \& Hopkins, 2010; Garcia, Lawton \& de Figueiredo, 2012).

\section{Research Design, Method and Procedure}

The qualitative type of research design was used to construct, checked and piloted the two interview protocols in order to collect data from the respondents, depending on philosophical assumptions of epistemologies and ontologies (Crotty, 1998) and underpinned by the interpretivism focuses as reality is multiple and epistemological constructionism, the knowledge is constructed and subjective (Creswell, 2009). For the collection of data from the respondents, the Interviews such as A and B were constructed for students and teachers respectively. The main indicators and aspects of above both protocols were as under:

- Base of students in English (basic knowledge in speaking, writing, reading and listening).

- Overcrowded classes (the strength of class).

- Integrated classes (students of various departments and institutes may use to attend remedial English classes in the same hall).

- Frequently change of teachers (majority of teachers is working on contract / as visiting faculty / regular basis).

- $\quad$ Payment of teachers (Regular / Irregular / insufficient).

- Availability / unavailability and proper / improper utilization of A. V. Aids (i.e. language laboratory, computers, multimedia, speakers, video CDs, etc.). 
- Regularity / irregularity, sincerity / insincerity and seriousness / non-seriousness of students.

- Classes fully loaded with activities / lack of activities (i.e. group discussions, debates, essays / paragraph writings, sentence structure, presentations, etc.).

\subsection{Research Questions}

Q.1. What is the perception of students and teachers about Remedial English Class and course?

Q.2. How students and teachers experience the Remedial English Class and course?

Q.3. What skills have been learned and improved by students through Remedial English Class and course?

Q.4. What problems have been faced by students that affect negatively on their learning?

Q.5. How teachers solve the problems of students?

\subsection{Population, Sample and Research Tools}

All teachers who teach remedial English and all students of university of Sindh who have attended the remedial English classes and course were constituted as the population of the study. Teachers of remedial English $(\mathrm{n}=5)$ and students $(n=40)$ of different departments and institutes were taken as the sample of the study. As the number of participants may be several and ranging from 1 or 2 to 30 or 40, depends on the need as to report details about each individual or site (Creswell, 2012). Simple random sampling technique was used to select the sample of the students and teachers. Interview protocols were used to collect the data from the students of different departments and institutes and teachers who teach remedial English at various departments and institutes.

\section{Results}

\subsection{Analysis of Students' Interview}

Q.1. What is the perception of students and teachers about Remedial English Class and course?

Thirty six (90\%) students perceived that this course would be beneficial to improve the reading, writing, listening and speaking skills of English language. There would be some modern instruments installed in labs to improve the skills through listening and watching the audio and video resources. Teachers should be well trained having good knowledge of content and pedagogy to deal with the students well to lead them towards the successful achievement of learning skills and its proper utilization for the betterment of their career and future. But after attending and completing the course their result and the perception was not like that was before attending the course. Only (30\%) students were found satisfied with the course as its output, as they were hoped and required as learning and acquiring as good grades.

Q.2. How students experience the Remedial English Class and course?

Twenty six (65\%) students said that the books were found suitable having many good exercises to learn but the environment of the class was no-supportive to learn well and easily. Sometimes written assignments were given and students try to submit before deadlines but no proper feedback system available to learn from the work done by students. These assignments provide an opportunity to have a writing practice nothing else to learn and improve the writing skills. No reading activity was done in classroom throughout the semester in order to learn reading and improve skills at all. Even though no listening activities were done, only teacher's lecture was the main resource to listen and no audio and video resources were used to provide some activities in classroom. Spoken was remained the main weak area of the students because for speaking students need to develop their confidence first and there was no activities of group discussions, presentations, debate, etc. The classrooms are overcrowded having 100 to 300 students attending the class or remedial English because students of many departments have combined to take class in some large halls and auditoriums where only lecture methods are used. Teachers have no time to listen the problems of students and check their assignment properly and give positive constructive feedback for the improvement of their skills.

Q.3. What skills have been learned and improved through Remedial English Class and course?

Twenty four (60\%) students said that the overall learning was remain satisfactory and we had an opportunity to listen good ascent of English language from teacher and few of our class mates who possess good type of skills and confidence to discuss things with the teacher during classroom discussions. It was observed and experienced that the classroom was conducted only for those few students and no attention was given to rest amount of students. Majority of students remained blank in order to learn any type of skills in English language to increase their confidence, 
growth and development regarding their studies and knowledge. But on the other side it was a good opportunity to listen and observe the teacher and students that how they have improved their language skills and confidence to speak at the front of hundreds of the audience. This whole process appreciated some students and dragged their attention to learn English because without having knowledge and skills of English language no one can progress well to become a successful professional in future. After having this type of realization many students have joined the English language centers running by private owners in their cities where they are living. Because at private language centers provide good supportive environment, time and practice to learn English skills within limited period of time.

Q.4. What problems have been faced by students that affect negatively on their learning?

Thirty four (85\%) students said that there were many problems they faced during their study at university specially attending the remedial English classes such as classes were conducted at other department that were at some distance to go to attend regularly; frequently change of teacher / tutor; irregularity and punctuality of teacher / tutors; strikes of different political parties, traders and transporters; classes boycott by students political parties; class boycott by teachers political and pressure groups; unavailability of books and material in markets; overcrowded classes; combined classes with the students of other departments and institutes; unavailability of furniture, white / black board, chalks / markers, duster, computer, internet facility, overhead projector, multimedia and audio visual aids; unavailability of language lab; unavailability of audio and video resources for language learning and practice; unavailability of dictionaries, related books, newspapers, magazines and thesaurus; improper system of assessment and evaluation depending on summative method of evaluation; unavailability of constructive feedback; unavailability of mentoring and monitoring system.

\subsection{Analysis of Teachers' Interviews}

Q.1. What is the perception of teachers about Remedial English Class and course?

Four $(80 \%)$ teachers perceived that this course would be beneficial for students to provide them a platform and opportunity to improve their all skills such as reading, writing, listening and speaking. It was also expected that through this course some modern instruments and language labs would be installed at department level or language center would be constructed for whole university students to improve their language skills. Many problems occurred and the main aims and objectives of the course were not achieved due to having some flaws and weak relationship between policy making and its implementation.

\section{Q.2. How much students have been benefited from the Remedial English Class and course?}

Four (80\%) teachers said that most of the students have not been benefited from the course and have not learnt good skills of speaking, writing, reading and listening of English language but only 30\% students have well enough skills, while (70\%) students have good knowledge and understanding about grammar. The main reason of no or less learning English language of students is weak management and administrative activities and interest, Untrained faculty, contractual faculty drawing irregular pay package with job insecurity, unavailability of all materials resources.

Q.3. What problems are faced by students in Remedial English Class and course that effect negatively on their language learning skills?

Three (60\%) teachers said that many problems have been faced by students during attending the remedial English classes such as classes were conducted at other department, away from their mother department; change of teacher / tutor; strikes of different political parties, traders, transporters, students political parties, teachers political and pressure groups; overcrowded classes and combined classes; unavailability of material resources, language lab, audio and video resources, dictionaries, books, newspapers, magazines and thesaurus; unavailability of constructive feedback, mentoring and monitoring system.

Q.4. How you interact and solve the problems of your students?

Five (100\%) teachers said that normally they have 300 to 500 students in their classes and it is very much difficult to deal with students individually. Most of the things are asked and discussed by students in their classes but students who have any matters, issues and problems are welcome to teacher office during counseling hours to discuss them in detail. After listening and discussion students are given some suggestions to do their work and overcome their problems too. But most of the problems remained unsolved due to unavailability of resources and materials. 


\section{Discussions}

Teachers are appointed as tutors on contractual basis and paying very low \& irregular pay package as well as insecurity of job that effects negatively on the class performance of the teachers and make passive to work for better teaching with planning. Integrated \& over crowded classes, less / no use of educational technology, low \& irregular pay packages of teachers, insecurity of Job, strikes of different stakeholders inside and outside of the university are directly as well as indirectly affect the performance of teachers and the regularity, sincerity and seriousness of the students. Some tutors come from college side to teach remedial English classes as they rush to be presented at university and classes and do not give proper counseling time to students. No mike, overhead projector, multimedia, computer, etc. are available to conduct remedial English classes in other departments whose management never helps, offers and avail any facility in class to use for better learning environment. For the English language skills (ELs) achievement gap (Fry, 2007) requires preparation and support of effective trained teachers who help to increase the student achievement and success (Cochran-Smith \& Fries, 2005), particularly for the helpless population of ELs (Gandara \& Maxwell-Jolly, 2006).

There were no good opportunities of professional trainings and refresher courses, do not get and even given them a part in syllabi change, use grammar translation method (GTM), no awareness of communicative teaching method (CTM), not using English language frequently in their classrooms with their students, no opportunity of reading, writing, speaking and listening to develop their skills, overcrowded classes, improper lesson planning, insufficient time allocation, improper classroom management and English is being taught as a subject not as a language. For direct impact on EL achievement the teachers have to play a central and pivotal role to negotiate (Menken \& Garcia, 2010), implement (Ricento \& Hornberger, 1996), and suggest the appropriate reforms for language policy (Levinson \& Sutton, 2001), as the crucial actors and enactors to implement policies properly in classroom practices. Because language policy guides teachers and students towards linguistic catalogues in educational settings (Menken \& Garcia, 2010) that also relates to broader societal perceptions, cultural and linguistic diversity (Dorner, 2011; Heineke, 2009; Valdés, 2000). But on the other hand most of the students do not ask questions, and their emphasis is on reading skill especially on aloud reading skill (Teevno, 2011).

\section{Conclusion}

On the bases of collected data the conclusion is that the importance of English language and its learning is accepted by the students with the dept of their heart and mind and the program of remedial English is also appreciated by them. But there are some sought of problems who do not allow the system to run smoothly to achieve the aims and objectives of the program. That's why the product means the students of the university are still not satisfied with the planning and procedure of the remedial English program. Still after many years of introducing the program the university is revolving around the first objectives of the program and still two giant objectives are left to work on them to achieve the good results.

\section{Suggestions}

- Language laboratory should be established in each department / institute for their own students like computer laboratories.

- Teachers should be appointed separately for each department / institute like other subjects of management, computer, etc, as they may maintain their laboratory and give much more guidance and time to their students.

- More time should be kept for Remedial classes during first and second semester of first year of undergraduate and previous classes.

- Only English should be allowed as the medium of instruction except other languages i-e, Sindhi, Urdu, Arabic, Persian, etc, and Islamiyat classes.

- Students should be taught through multimedia, computers and over head projector (OHP).

- Number of activities should be designed by teachers for students in order to give more opportunities to explore and increase their talent and confidence. 


\section{References}

Aadil, N. (2010). Assessing quality of higher education in Pakistan. Presented at 3rInternational Conference on Assessing Quality in Higher Education, Lahore, Pakistan.

Al-Belushi, A.S. (2003). A Study of Omani Teachers' Careers': Unpublished PhD thesis, Centre for English Language Teacher Education, University of Warwick, UK.

Ayto, J. (1999). Twentieth-Century Words. New York: Oxford University Press.

Batool, Z., \& Qureshi, R. H. (2007). Quality assurance manual for higher education in Pakistan, Higher Education Commission, Pakistan. City: Islamabad.

Denton, C., Bryan, D., Wexler, J., Reed, D., \& Vaughn, S. (2007). Effective instruction for middle school students with reading difficulties: The reading teacher's sourcebook. Austin, TX: Vaughn Gross Center for Reading and Language Arts at the University of Texas at Austin.

Burchfield, R. W. (1996). The New Fowler's Modern English Usage. New York: Oxford University Press, (ed.). Widely respected guide to "correct" usage.

Canagarajah, A.S. (1999a). Interrogating the Native Speaker Fallacy', in G. Braine (ed.), Non-Native Educators in English Language Teaching(77-92). Mahwah, NJ: Lawrence Erlbaum.

Cochran-Smith, M., \& Fries, M. (2005). The AERA panel on research and teacher education: Context and goals. In M. Cochran-Smith \& K. Zeichner (Eds.), Studying teacher education: The report of the AERA panel on research and teacher education (pp. 37-68). Mahwah, NJ: Lawrence Erlbaum.

Dorner, L. (2011). Contested communities in a debate over dual-language education: The import of "public" values on public policies. Educational Policy, 25, 577-613. http://dx.doi.org/10.1177/0895904810368275

Creswell, J.W. (2009). Research design: Qualitative, quantitative and mixed methods approaches (3 ${ }^{\text {rd }}$ ed.). London, England: Sage Publications.

Creswell, J.W. (2012). Educational Research, Planning, Conducting, and Evaluating Quantitative and Qualitative Research ( $4^{\text {th }}$ ed.). Boston, USA: Pearson Education, Inc.

Crotty, M. (1998). The foundations of social research: Meaning and perspective in the research process. London, England: Sage Publications.

Estrada, J.C.A. (2016). The Level of English Oral Reading Fluency among Abot - Alam Secondary Learners. World Journal of English Language, 6(3), 9-23. http://dx.doi.org/10.5430/wjel.v6n3p9

Francis, D. J., Fletcher, J. M., Stuebing, K. K., Lyon, G. R., Shaywitz, B. A., \& Shaywitz, S. E. (2005). Psychometric approaches to the identification of LD: IQ and achievement scores are not sufficient. Journal of Learning Disabilities, 38(2), 98-108. http://dx.doi.org/10.1177/00222194050380020101

Fry, R. (2007). How far behind in math and reading are English language learners? Washington, DC: Pew Hispanic Center.

Gándara, P., \& Hopkins, M. (2010). The changing linguistic landscape of the United States. In P. Gándara \& M. Hopkins (Eds.), Forbidden language: English learners and restrictive language policies (pp. 7-19). New York, NY: Teachers College Press.

Gándara, P., \& Maxwell-Jolly, J. (2006). Critical issues in developing the teacher corps for English learners. In K. Téllez \& H. C. Waxman (Eds.), Preparing quality educators for English language learners: Research, policies, and practices (pp. 99-120). Mahwah, NJ: Lawrence Erlbaum.

García, E. E., Lawton, K., \& de Figueiredo, D. (2012). The education of English language learners in Arizona: A history of underachievement. Teachers College Record, 114, 1-18.

Government-of-Pakistan. (2009). National Education Policy 2009. Ministry of Education: Islamabad.

Gray, W. S., \& Rogers, B. (1956). Maturity in reading: Its nature and appraisal. Chicago, USA: University of Chicago Press.

Hale, C., \& Jessie, S. (1999). Wired Style: Principles of English Usage in the Digital Age. New York: Broadway Books. Wired magazine is an influential publication about computer technology.

Harn, B. A., Stoolmiller, M., \& Chard, D. J. (2008). Measuring the dimensions of alphabetic principle on the reading development of first graders. Journal of Learning Disabilities, 41(2), 143-157. 
http://dx.doi.org/10.1177/0022219407313585

Harvey, S. (1998). Nonfiction matters: Reading, writing, and research in grades 3-8. Portland, ME: Stenhouse Publishers.

Hasbrouck, J., \& Tindal, G. A. (2006). Oral reading fluency norms: A valuable assessment tool for reading teachers. Reading Teacher, 59(7), 636-644. http://dx.doi.org/10.1598/RT.59.7.3

Hayakawa, S. I. (1978). Language in Thought and Action (4 ${ }^{\text {th }}$ ed.). New York: Harcourt Brace Jovanovich. Classic work on semantics.

Heineke, A.J. (2015). Negotiating Language Policy and Practice: Teachers of English Learners in an Arizona Study Group. Educational Policy, 29(6), 843-878. http://dx.doi.org/10.1177/0895904813518101

Heineke, A. J. (2009). Teachers' discourse on English language learners: Cultural models of language and learning (Unpublished dissertation). Arizona State University, Tempe.

Howe, E.R. (2005). Japan's Teacher Acculturation: Critical Analysis through Comparative Ethnographic Narrative. Journal of Education for Teaching, 31(2), 121-31.

Iqbal, A. (2004). Problems and prospects of higher education in Pakistan. University of Arid Agriculture, Rawalpindi.

Iqbal, M. J., \& Ahmed, M. (2010). Enhancing quality of education through e-learning: the case study of Allama Iqbal Open University. The Turkish Online Journal of Distance Education, 11(1), 84-97.

Irfan, S., \& Kee, D. (2013). Critical Success Factors of TQM and its Impact on Increased Service Quality: A Case from Service Sector of Pakistan. Middle-East Journal of Scientific Research, 15(1), 61-74. http://dx.doi.org/10.5829/idosi.mejsr.2013.15.1.828.

Ismail, M. (2010). Quality Enhancement Cells and Self-Assessment Report Writing Method. City: University of AJK Muzaffarabad.

Jenkins, J. R., Hudson, R. F., \& Johnson, E. S. (2007). Screening for at-risk readers in response to intervention framework. School Psychology Review, 36(4), 582-600. https://www.researchgate.net/publication/265032148.

Katzir, T., Kim, Y., Wolf, M., O’Brien, B., Kennedy, B., \& Lovett, M., et al. (2006). Reading fluency: The whole is more than the parts. Annals of Dyslexia, 56(1), 51-82. http://dx.doi.org/10.1007/s11881-006-0003-5

König, J., Lammerding, S., Nold, G., Rohde, A., Strauß, S., \& Tachtsoglou, S. (2016). Teachers' Professional Knowledge for Teaching English as a Foreign Language: Assessing the Outcomes of Teacher Education. Journal of Teacher Education, 67(4), 320-337. http://dx.doi.org/10.1177/0022487116644956.

Levinson, B. A. U., \& Sutton, M. (2001). Introduction: Policy as/in practice-A sociocultural approach to the study of educational policy. In M. Sutton (Ed.), Policy as practice: Toward a comparative sociocultural analysis of educational policy (pp. 1-22). Westport, CT: Ablex.

McCrum, Robert, William C., \& Robert M.N. (1986). The Story of English. New York: Viking.

Memon, G. R. (2007). Education in Pakistan: The key issues, problems and the new challenges. Journal of Management and Social Sciences, 3(1), 47-55.

Menken, K., \& García, O., eds. (2010). Negotiating language policies in schools: Educators as policymakers (pp. 1-10). New York, NY: Routledge.

Mencken, H. L. (1963). The American Language: An Inquiry into the Development of English in the United States. In Raven I. McDavid, Jr., (ed.), Classic readable and influential examination of the new stream. New York: Alfred A. Knopf.

Morrow, L., \& Tracey, D. (2012). Lenses on Reading, Second Edition: An Introduction to Theories and Models (2 ${ }^{\text {nd }}$ ed.). New York: Guilford Press

National Council of Teachers of English. (2006). NCTE Principles of Adolescent Literacy Reform. Retrieved September 21, 2015 from http://www.ncte.org/library/NCTEFiles/Resources/PolicyResearch/AdolLitPrincples.pdf

National Clearinghouse for English Language Acquisition [NCELA]. (2012). English learner data clearinghouse. Retrieved from http://www.ncela.gwu.edu/data/dataclearinghouse

O’Sullivan, M.C. (2004). The Usefulness of Lesson Observation in a Primary Teachers' INSET Programme in 
Namibia'. Journal of Education for Teaching, 30(1), 5-23. http://dx.doi.org/10.1080/0260747032000162280

Oxford American Dictionary and Language Guide, (1999). New York: Oxford University Press.

Pikulski, J., \& Chard, D. (2005). Fluency: Bridge between decoding and reading comprehension. Reading Teacher, 58, 510-519. http://dx.doi.org/10.1598/RT.58.6.2

Pyles, Thomas \& John, A. (1982). The Origins and Development of the English Language. New York: Harcourt Brace Jovanovich.

Rasinski, T., Rikli, A., \& Johnston, S. (2009). More than automaticity? More than a concern for the primary grades? Literacy Research and Instruction, 48(4), 350. http://dx.doi.org/10.1080/19388070802468715

Rasinski, T. (2006), Reading Fluency Instruction: Moving Beyond Accuracy, Automaticity, and Prosody. The Reading Teacher, 59, 704-706. http://dx.doi.org/10.1598/RT.59.7.10

Rasinski, T. (2004). Creating Fluent Readers. What Research Says About Reading? Educational Leadership, 61(6), 46-51.

Ricento, T., \& Hornberger, N. (1996). Unpeeling the onion: Language planning and policy and the ELT professional. TESOL Quarterly, 30, 401-426. http://dx.doi.org/10.2307/3587691

Roberts-Holmes, G. (2003). Towards an Understanding of Gambian Teachers' Complex Professionalism. Teachers and Teaching: Theory and Practice, 9(1), 35-45. http://dx.doi.org/10.1080/1354060032000049896

Schreiber, P. A. (1991). Understanding prosody's role in reading acquisition. Theory in to Practice, 30, 158-164. http://dx.doi.org/10.1080/00405849109543496

Seyfried, E. (2007). Indicators for quality in VET: to enhance European cooperation. City: Office for Official Publications of the European Communities: Luxembourg. Assessing Quality of English Teachers at Secondary level in Punjab, Pakistan

Shah, S. (2010). Higher Education Expansion in Pakistan and Issues of Quality. Presented at 3rd International Conference on Assessing Quality in Higher Education, Lahore, Pakistan.

Shami, P. A., \& Hussain, K. S. (2006). Development of education in Pakistan: Academy of Educational Planning and Management, Ministry of Education.

Simon-Madea, A. (2004). The Complex Construction of Professional Identities: Female EFL Educators in Japan Speak Out. TESOL Quarterly, 38(3), 405-36. http://dx.doi.org/10.2307/3588347

Stahl, S. A., \& Kuhn, M. R. (2002). Making it sound like language: Developing fluency. The Reading Teacher, 55, 582-584.

Strunk, William Jr., \&White, E. B. (1979). The Elements of Style ( $3^{\text {rd }}$ ed.). New York: Macmillan.

Tafa, E.M. (2004).Teacher Socialisation: A Critical Qualitative Analysis of the Teaching Methods of Seven New Teachers in Botswana Junior Secondary Schools'. International Journal of Educational Development, 24, 757-58. http://dx.doi.org/10.1016/S0738-0593 (01)00046-3

Teevno, R. A. (2011). Challenges in Teaching and Learning of English at Secondary Level Class X. International Journal of Human Resource Studies, 1(2), 27 - 35.

Tsui, A.M. (2003). Understanding Expertise in Teaching: Case Studies of ESL Teachers. Cambridge: Cambridge University Press.

Ullah, M. H. (2005). Comparison of the quality of higher education in public and private sector institutions in Pakistan. University of Arid Agriculture, Rawalpindi.

United Nations Educational, Scientific and Cultural Organization. (1983). Planning and organizing reading campaigns: A guide for developing countries. France: Workshop of UNESCO, 9.

Valdés, G. (2000). Bilingual individuals and language-based discrimination: Advancing the state of the law on language rights. In R. D. González \& I. Melis (Eds.), Language ideologies: Critical perspectives on the official English movement (Vol. 1, pp. 140-170). Mahwah, NJ: Lawrence Erlbaum.

Wolf, M., \& Katzir-Cohen, T. (2001). Reading fluency and its intervention. Scientific Studies of Reading, 5(3), 211-239. http://dx.doi.org/10.1207/S1532799XSSR0503_2 